\title{
O PRÓLOGO DE JOÃO: ATRIBUTOS CONFERIDOS AO LOGOS
}

\author{
Antonio Wardison* \\ Prof. Dr. Cézar Teixeira** \\ Prof. Me. José Pedro Teixeira de Jesus***
}

\section{RESUMO}

Em primeiro lugar, a reflexão a seguir se coloca como um esforço necessário para se percorrer e precisar o conceito "logos". A sua compreensão no helenismo, no judaísmo e no cristianismo é, sem dúvida, uma compreensão que nos faz entender melhor o significado do Logos aplicado a Jesus. Em segundo lugar, os atributos conferidos ao Logos nos fazem mergulhar nas mais profundas raízes de um conceito que vai além das suas premissas literárias, para esboçar a grandeza de um princípio tão caro à nossa existência. Graças ao Logos essa existência é coroada pela natureza divina à qual emana dele e com ele mantém um profundo relacionamento capaz de elevar a criação à própria natureza do seu Criador.

Palavras-chave: Logos. Jesus. São João. Evangelho.
Keywords: Logos. Jesus. St. John. Gospel.

\footnotetext{
* Antonio Wardison, Mestrando em Filosofia pela PUCSP. Especialista em Psicopedagogia, Filosofia existencial e Catequese. Licenciado em Filosofia e bacharelando em Teologia pelo UNISAL.
} 


\section{INTRODUÇÃO}

O presente artigo tem por finalidade abrir um debate e reflexão sobre o prólogo de São João e os atributos conferidos ao Logos. Decidimos desenvolver este tema, não por falta de trabalhos já realizados, mas, pelo fato desta reflexão ter se intensificado a partir da exortação apostólica pós-sinodal Verbum Domini. O papa Bento XVI elegeu o prólogo de São João como guia do seu escrito. ${ }^{1}$ Não se trata, contudo, de uma reflexão sobre a exortação apostólica, nem tão pouco sobre o prólogo do quarto evangelho; mas, sim, os atributos conferidos ao Logos no Evangelho de São João.

O prólogo joanino é uma das passagens neotestamentárias mais discutidas. Para muitos, trata-se de uma composição anterior ao próprio Evangelho. "Naquilo que era primitivamente um hino aparentemente de procedência gnóstica e que celebrava a figura de um revelador, introduziu-se a figura do Batista e se cristianizou este Logos com Jesus de Nazaré". ${ }^{2}$

Fundamentalmente, o prólogo é uma introdução ao evangelho de João, porém uma introdução que já aparece como síntese de tudo aquilo que irá se discutir durante todo escrito joanino. Destaca-se a figura de Jesus como o revelado do Pai, na história, num mundo dos homens. O Logos é o personagem principal e seu real sentido encontra-se discutido entre as demais hipóteses: uma criação de João; a mesma palavra criadora de Gêneses; o logos de Heráclito, dos estóicos; é um conceito em referência a sabedoria veterotestamentária. Para tanto, vamos desenvolver a dimensão cristológica do Logos, sua difusão no helenismo e no judaísmo. Por fim, veremos os atributos conferidos ao Logos.

** Prof. Cézar Teixeira, Doutor em Teologia Bíblica pela Pontifícia Universidade Santo Tomás de Aquino de Roma, onde defendeu a tese sobre a importância da mesa de refeição no anúncio da traição em Mc 14,17-21. Atualmente é professor e diretor adjunto da Faculdade de Teologia da PUCSP, onde leciona Sagrada Escritura.

*** Prof. José Pedro Teixeira de Jesus é Mestre em Teologia Bíblica pela Pontifícia Universidade Santo Tomás de Aquino em Roma, onde defendeu a tese sobre a traição de Judas em Mc 14,10-11. Leciona no Instituto de Teologia de Santo André, na área de Sagrada Escritura.

1 Cf. EXORTAÇÃO APOSTÓLICA PÓS-SINODAL VERBUM DOMINI, n. 5. São Paulo: Paulinas, 194, p. 11, 2010.

2 CALLE, Francisco de La. A Teologia do Quarto Evangelho. (Trad.) José Raimundo Vidigal. São Paulo: Paulinas, 1985, p. 39. 


\section{O LOGOS E A CRISTOLOGIA}

Os quatro evangelhos, no seu conjunto, têm como premissa as palavras e os gestos de Jesus como a célula germinal dos textos existentes. Nesta perspectiva, não se pode conceber uma cristologia que prescinda desta máxima. Embora outros títulos atribuídos a Jesus sejam mais freqüentes em todo o Novo Testamento, no texto do quarto Evangelho "Jesus, o Logos", aparece somente quatro vezes fazendo-se referência a Cristo ${ }^{4}$, mesmo assim, este título ocupa um lugar predominante na cristologia clássica da Igreja antiga. Tal substantivo carrega, em si, uma variedade de sinônimos, ${ }^{5}$ e ao longo da história, uma variedade de significados.

Queremos neste momento nos deter sobre os significados mais relevantes na intenção de conceituar com maior precisão o significado do Logos ao ser atribuído a Jesus.

\subsection{O Logos no Helenismo}

É inegável a vasta literatura existente sobre este assunto e não podemos neste momento discorrer sobre ela. O que mais se faz necessário ressaltar é a grande difusão do conceito helênico sobre o logos no mundo antigo. Desenvolveu tal temática: Heráclito; os estóicos, que conceberam o logos como algo abstrato; Platão, com o conceito idealista que não permite a idéia da encarnação do Logos; o próprio Santo Agostinho que, embora tenha feito uma analogia entre o logos apresentado na filosofia com aquela do quarto evangelho, a aplica somente na terminologia e não como a mesma concepção; os gnósticos, que apresentam o logos como um ser mitológico ligando Deus aos homens, sem, contudo, assumir o espaço da história e de uma verdadeira encarnação. Tudo isto, o autor do quarto evangelho

3 Para o desenvolvimento desta parte utilizamos: CULLMANN, O. Cristologia Del Nuevo Testamento, Salamanca: Sigueme, 1997, p. 327-349.

4 Cf. Jo 1,$1 ; 14$.

5 A saber: palavra, discurso, menção, declaração, afirmação, dito, provérbio, resolução, ordem, proclamação, doutrina, oráculo, verbo, matéria, questão, discurso, palavra, colóquio, narrativa, oração, discurso, totalidade, significado, argumentação, razão, pensamento, causa, fundamento, justificação, causa. RUSCONI, Carlos. Dicionário do Grego do Novo Testamento. São Paulo: Paulus, 2005, p. 288. 
certamente não o ignorou no seu trabalho. Tais escritos, de alguma forma, investiram o "Logos" de uma compreensão da filosofia grega, bem como, o próprio judaísmo tardio. Certamente esta compreensão grega sobre o Logos irá influir no prólogo de São João, porém, não de maneira decisiva. O Logos joanino será apresentado como a revelação de Deus na pessoa de Jesus de Nazaré. ${ }^{6}$

\subsection{O Logos no Judaísmo}

Sem dúvida, no judaísmo, a filosofia grega acabou influenciando a concepção do logos, sobretudo no judaísmo tardio. Entretanto, no judaísmo mais remoto, Gênesis 1 por exemplo, o Logos está facilmente identificado com a própria Palavra de Deus. Esta distinção é conceitual e não aparece claramente nos textos judaicos tardios. Também no Evangelho de São João as duas realidades estarão presentes. Dessa forma, não temos elementos suficientes para afirmar que no prólogo encontramos uma tradição pura que nos remete ao divino ou ao "pagão". Seria empobrecer o texto se quiséssemos estabelecer uma fronteira. As duas realidades estão presentes no Antigo Testamento e certamente influenciaram os escritos joaninos. ${ }^{7}$

É diante desta provável aporia ${ }^{8}$ que surge a seguinte questão: quais são as tradições do antigo testamento que nos ajudam a compreender a visão dos Logos no judaísmo? O livro de Gênesis 1 e 2 nos apresenta todo o relato da criação que tem como ponto de partida a Palavra de Deus, palavra que é ação, verbo, capaz de criar todas as coisas. Verificamos a mesma realidade no Salmo 33,6. Como mediador, a palavra é aquela que cura (SI 107,20). Temos ainda o SI 147,15; Is 55. A personificação da Palavra como

\footnotetext{
Cf. EXORTAÇÃO APOSTÓLICA, op. cit. n. 7.

Além do quarto evangelho, o Logos será mencionado em 1Jo 1,1 e em Ap 19,13.

8 O sentido do $\lambda o^{\prime} \gamma$ s, aqui utilizado pelo evangelista, não é proveniente da filosofia grega, mas sua procedência é semítica, pois no Antigo Testamento se comprova que o $\lambda$ ó$_{0}$ o é apresentado como uma pessoa (como se pode observar no SI 33,6 e em $\operatorname{Pr}$ 8,27-30). HENDRIKSEN, William. O Evangelho de João. São Paulo. (trad). Elias Dantas e Neuza Batista. São Paulo: Cultura cristã, 2004, p. 100. Assim também, para alguns estudiosos, o $\lambda o^{\prime} \gamma \circ \varsigma$ em João fica ainda mais claro se referenciado a Gêneses (1,3.6.9.11.14.20.24.26.28), pois é por meio do "verbo" que Deus cria o mundo e, também por ele, a criação e o ho-

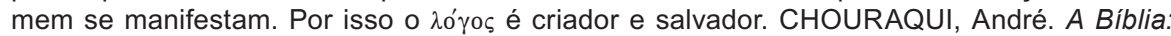
Iahonan (O Evangelho segundo João). Rio de Janeiro: Imago, 1997, p. 46.
} 
guerreiro (Sb 18,15), como Sabedoria ( $\operatorname{Pr} 8,22-27)$, como Luz (Sb 7,26); como a Sabedoria que desencadeia ódio da parte do mundo ( $\operatorname{Pr} 1,28$; Ecl 24,7).

\subsection{O Logos aplicado a Jesus}

Somente no prólogo do quarto evangelho é que São João atribui a Jesus o título de Logos. Isto significa que, para o Novo Testamento, tal título não ocupa um lugar central como o Filho do Homem, como Cristo, etc. A aplicação do título de Logos para Jesus, em João, tem a finalidade de preencher uma lacuna deixada pelos evangelhos sinóticos, a saber: todos eles apresentam Jesus a partir da criação, ${ }^{9}$ João pretende apresentar Jesus desde toda a eternidade, superando até mesmo o livro de Genesis, pois, não inclui Jesus como obra criada por Deus, mas sim, como co-autor ao lado do Pai em toda a obra da criação. Assim, este título se torna indispensável para compreender o autor que pretende apresentar a relação de Deus com Jesus e a sua pré-existência, ${ }^{10}$ em todo o seu relato.

Por outro lado, sabemos que Logos significa Palavra, e nesse sentido, afirmar que Jesus é o Logos permite-nos afirmar que Jesus é a Palavra. Tal raciocínio é análogo àquele que nos leva a afirmar que Jesus é o Caminho, a Verdade, a Vida, Deus feito homem. Assim, não se pode afirmar com facilidade que o Logos não tenha sido tratado em outros escritos do Novo Testamento. Ao dizer que Jesus é a Palavra, de maneira indireta, estamos afirmando que Jesus é o Logos, e, neste sentido, o Novo Testamento nos apresenta Jesus como a Palavra viva de Deus em vários pontos dos seus escritos. No evangelho de João, portanto, merecem destaque os significados dos seguintes termos: "Palavra" e "Verbo". Ora, enquanto "Palavra de Deus", o Logos quer significar o conteúdo da revelação e da criação (Jo 1,3.18; 1Cor 8,6; Cl 1,17; $\mathrm{Hb}$ 1,1-2). A palavra evidencia a criação de todas as coisas. É um sinal que expressa a vontade e a força de Deus, sua sabedoria e ação (1Cor 1,30; Ef 3,8-11; Cl 2,2-3). Ela também revela os propósitos escritos no coração de Deus (Jo 1,3; Cl 1,18; 4,34; 5,30; 6,38). O Logos é

9 Princípio do Evangelho de Jesus Cristo [...] (Mc 1,1); Livro da origem de Jesus Cristo [...] (Mt 1,1); [...] filho de Enós, filho de Set, filho de Adão, filho de Deus (Lc 3,38).

10 EXORTAÇÃO APOSTÓLICA, op. cit. n. 6. 
o próprio verbo divino, aquele que dá sentido a todas as coisas $(\mathrm{Cl} 1,17) .{ }^{11}$ O evangelho de São João tem uma intenção: traçar uma linha direta entre a vida humana de Jesus como o centro da revelação plena da verdade divina. Deus, que por sua vez é incansável, torna-se atingível pela Palavra: "primeiro na criação; depois na encarnação, porque este Logos chega a converter-se em homem. E é então que sabemos que Jesus de Nazaré e o Logos se identificam". ${ }^{2}$

\section{ATRIBUTOS CONFERIDOS AO LOGOS}

\subsection{O Logos e a Eternidade}

"No princípio era o Verbo" (Jo 1,1a). ${ }^{13}$ O prólogo de João, logo no seu início, evidencia a eternidade do Logos. Este se apresenta fora do tempo, antes de toda criação. ${ }^{14}$ Ele é um ser infinito, eterno e se revela nas Escrituras como um ser além do tempo ou fora do tempo. Assim, o Logos não tem uma substância, como tem as coisas criadas no mundo, Ele é consubstancial ao Pai. Na frase, acima destacada, nota-se que a ação está no imperfeito, para indicar uma ação inacabada, isto é, uma ação que se prolonga no tempo. E ao dizer que o Logos estava no princípio, João quer dizer que Ele "existe eterna e infinitamente antes de criar o universo finito. Ele é anterior a toda criação, no céu e na terra, e está acima e independente dela".15

No primeiro versículo do Prólogo, o começo não pode, com efeito, ser aquele de que falam os Sinóticos e que designa o início do ministério de Jesus; também não é o início metafísico que certos Padres gregos quiseram discernir aqui. A expressão en arkhéi pouco freqüente na língua profana, remete muito nitidamente ao primeiro versículo da

11 FIGUEREDO, Pedro. A Questão do Logos e os Discursos de Jesus no Evangelho de São João. In Revista de Ciência das religiões, Vol. 1. (2008), p. 34.

12 CALLE, Francisco de La. A teologia do Quarto Evangelho, p. 39.

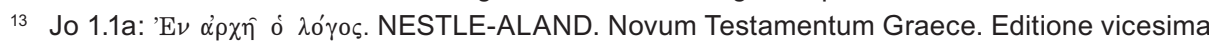
septima revisa. Stuttgart: Deutsche Bibelgesellschaft, 1993. (Todos os textos, em grego, aqui utilizados, foram retirados desta edição. A tradução para o português é nossa).

14 Cf. VERBUM DOMINI, EXORTAÇÃO APOSTÓLICA PÓS-SINODAL SOBRE A PALAVRA DE DEUS NA VIDA E NA MISSÃO DA IGREJA, n. 7.

15 FIGUEREDO, Pedro. A questão do Logos e os discursos de Jesus no Evangelho de São João, p. 100; VERBUM DOMINI, n. 6. 
Bíblia: No início Deus criou os céus e a terra [...] encontramos aqui a afirmação de uma "existência" que precede (ou preside a) esse começo. Desde esse começo, "havia" ou "existia" o Logos; desde antes do começo do mundo, o Logos estava lá [...]. Podemos discutir a tradução do ên. Substituindo-o por "existia", sublinha-se a posição e a permanência do Logos no ser [...]. Assim, sou levado a preferir uma tradução mais neutra que se interessa mais pelo "princípio": "havia", ou simplesmente "era". ${ }^{16}$

É importante notar que Jesus, na última semana do seu ministério, declara, aos seus discípulos, a sua eternidade: "E agora glorifica a mim tu, Pai, junto a ti mesmo, com a glória que eu tinha antes do mundo existir junto a ti" (Jo 17,5)..$^{17}$ Aqui, o verbo "glorificar" está conjugado no aoristo no modo imperativo (no sentido de um pedido, desejo). O verbo "ter" no imperfeito, expressa uma ação inacabada que se prolonga no tempo. Por isso, Jesus expressa seu profundo desejo de voltar para a glória do Pai, na comunhão plena com ele. ${ }^{18}$

Em outras passagens da Escritura, se verifica a eternidade de Jesus ao afirmar a sua existência antes mesmo de Abraão: "[...] antes de Abraão vir a ser eu sou" (Jo 8,58)..$^{19}$ Novamente nota-se que o Logos precede toda existência, antes mesmo dos profetas. Porque Cristo estava na glória do Pai, numa relação de comunhão eterna. Jesus afirma, de fato, ser verdadeiramente Deus em sua totalidade e aqui se prescreve tal perspectiva nos atributos do poder, da eternidade e da sabedoria. Também, quando Jesus afirma ser o alfa e o ômega: "Eu o alfa e o ômega, o primeiro e o último,

16 LÉON-DUFOUR, XAVIER. Leitura do Evangelho Segundo João. Vol. 1. São Paulo: Loyola, 1996, p. 59-60.

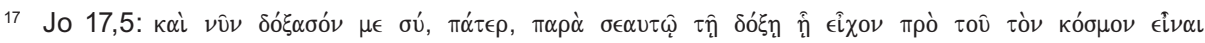
$\pi \alpha \rho \grave{\alpha}$ бoí.

18 CHOURAQUI, André. op. cit., p. 249, afirma: "a glória que eu tinha: A única glória à qual léshoua' pretende á aquela de estar junto de $\mathrm{YHWH}$, em sua presença. Ele tem consciência da pré-existência e da permanência divinas de seu ser".

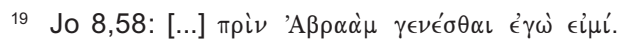


o princípio e o fim" (Ap 22,13) ${ }^{20}$ Ele nos apresenta aqui a sua eternidade, a eternidade do Logos. ${ }^{21}$

\subsection{O Logos e o relacionamento com Deus}

"E o Verbo estava junto a Deus" (Jo 1,1b). ${ }^{22}$ Ora, já verificada a eternidade do verbo, o prólogo agora evidencia o relacionamento dele com o Pai: a comunhão entre essas duas pessoas. ${ }^{23}$ Esta comunhão se estendeu por todo o ministério terreno de Jesus, ${ }^{24}$ como é possível observar na sua oração e nos seus ditos, quando afirmava que o seu desejo era o desejo do Pai: "pois desci do céu não para que faça a minha vontade, mas a vontade daquele que me enviou" (Jo 6,38). ${ }^{25} \mathrm{O}$ verbo aqui expresso, $\kappa \alpha \tau \alpha \beta \epsilon ́ \beta \eta \kappa \alpha$, indica uma ação realizada há pouco tempo e que se prolonga até ao presente da

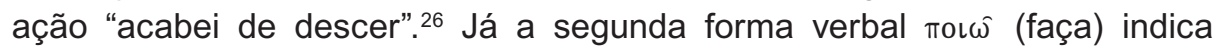
uma ação concebida como desejável, o que expressa uma vontade particular de Jesus em está numa intensa conformidade com o Pai. A terceira forma verbal, $\pi \epsilon \mu \psi \alpha \nu \tau$ cós (enviou), já indica uma ação plenamente realizada, quer dizer, o verbo tem a missão de cumprir com a vontade divina: desde a eternidade o verbo e o Pai viveram em comunhão plena, seja no plano de toda criação ou da vontade de realização. "Não se trata de uma qualidade acrescentada ao homem Jesus, mas de uma entidade total e real: Jesus é Deus". ${ }^{27}$ No entanto, embora eles vivam em comunhão, o verbo goza de uma identidade própria. Nos Evangelhos, o que mais sinaliza ou expressa

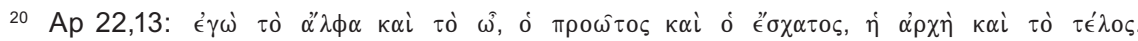

21 FIGUEREDO, Pedro. A questão do Logos e os discursos de Jesus no Evangelho de São João, p. 38.

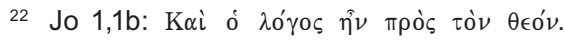

23 LÉON-DUFOUR, Xavier. Leitura do Evangelho Segundo João. Vol. 1. São Paulo: Loyola, 1996, p. 63: "O que, em todo caso, implica o teor do estíquo $1 b$ é que entre o Logos e Deus existe uma 'diferença'. Com efeito, tudo o que é dito o é a partir do Logos e não do ponto de vista do próprio Deus (designado pela expressão hò theós); assim, não se diz que Deus está junto do Logos. Contudo, o teor do estíquo sublinha igualmente, em todos os casos de leitura, que o Logos está unido intimamente a Deus".

24 VERBUM DOMINI, n. 7.

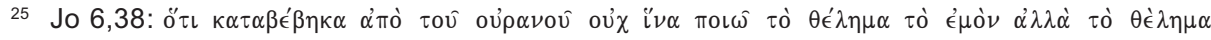

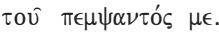

26 FIGUEREDO, Pedro. A Questão do Logos e os Discursos de Jesus no Evangelho de São João, p. 39.

27 CALLE, Francisco de La. A Teologia do Quarto Evangelho, p. 46. 
a comunhão dessas duas pessoas é a oração: Lc 3,21-22; 6,12-13; 9,2829 ; 10,21; 22,31-34.42, 23,34.46; Mt 19,13-15; 26,39.42; 27,46; Jo 11,41-42; 12,27-28; 17,11.20-26; Mc 14,36; 15,34. É pertinente observar o que afirma a Exortação Apostólica Verbum Domini:

A tradição patrística e medieval, contemplando esta "Cristologia da Palavra", utilizou uma sugestiva expressão: O Verbo abreviou-se. Na sua tradição grega do Antigo Testamento, os Padres da Igreja encontravam uma frase do profeta Isaías - que o próprio São Paulo cita - para mostrar como os caminhos novos de Deus estivessem já preanunciados no Antigo Testamento. Eis a frase: 'O Senhor compendiou a sua Palavra, abreviou-a' (Is 10,23 ; Rm 9,28). O próprio Filho é a Palavra, é o Logos: a Palavra eterna fez-Se pequena; tão pequena que cabe numa manjedoura. Fez-Se criança, para que a Palavra possa ser compreendida por nós. Desde então a Palavra já não é apenas audível, não possui somente uma voz; agora a Palavra tem um rosto, que por isso mesmo podemos ver: Jesus de Nazaré. ${ }^{28}$

Todas essas referências falam da oração de Cristo em íntima união com o Pai, sempre no caráter daquele que cumpre a vontade de Deus, assim como fala a Escritura: "[...] e o verbo estava junto a Deus" (Jo 1,1b). ${ }^{29}$ Há uma comunhão eterna entre o verbo e Deus: "Deus se faz presente no Logos e isto antes da constituição do mundo, no tempo infinito de Deus. O logos é Deus e está junto de Deus". ${ }^{30}$

\subsection{O Logos e a Eternidade}

"E o Verbo era Deus" (Jo 1,1c). ${ }^{31}$ Esta proposição demonstra, substancialmente, que o logos é o próprio Deus, igual ao Pai na sua natureza. Destarte, ao trazer tal afirmação, expressa também e de uma vez por todas, a eternidade do logos. Ainda mais, o verbo jîv (era) indica a existência contínua e atemporal do logos, pois em todas as situações e lugar ele é

\footnotetext{
28 VERBO DOMINI, n. 12.

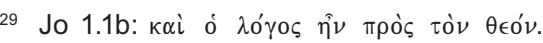

30 CALLE, Francisco de La. A Teologia do Quarto Evangelho, p. 42.

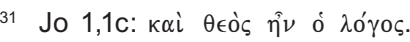


Deus. O Evangelho de João destaca a divindade do verbo em muitos momentos: pelos sinais, testemunho, declarações (Eu sou!), ressurreição. ${ }^{32} \mathrm{Na}$ divindade do verbo se contempla Cristo como testemunha fiel do Pai. Ao testemunhar o Pai, ele revela aquele que o enviou. Portanto o testemunho implica revelação. ${ }^{33}$

Em João, há duas declarações que explicitam a divindade de Jesus. A primeira está em referência à resposta de Natanael: "Respondeu a ele Natanael: Rabi, tu és o Filho de Deus, tu és rei de Israel" $(1,49) .{ }^{34}$ Ora, esta declaração de Natanael faz notar que ele observa, no Cristo, algo de diferente, como uma pessoa de natureza inigualável. No Evangelho de João,

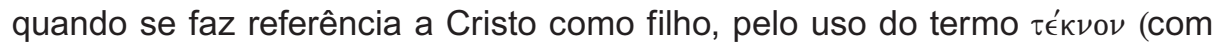
o substantivo viós), se fala de uma união eterna, de um filho que não passou a existir num determinado momento, mas que, por toda a eternidade, é a expressão do Pai, assim como ele afirma: "Quem viu a mim viu o Pai" (Jo 14,9). ${ }^{35}$

Por isso, o Logos existe por toda a eternidade. A segunda declaração se verifica em Tomé: "Respondeu Tomé e disse a ele: meu Senhor e meu Deus"! (Jo 20,28). ${ }^{36}$ Nesta expressão encontra-se o centro de toda idéia da divindade de Jesus no evangelho joanino. Ora, Tomé, em tal proposição, utiliza o substantivo kúpıoৎ para se referenciar a Cristo como Senhor (no âmbito da divindade de Cristo e não na esfera do humano), diferente do termo $\delta \in \sigma \pi 0 \tau \eta \dot{s}$, que remete a um senhorio provincial, governamental. ${ }^{37}$

O próprio Jesus, em Jo 4,25-26, afirma ser o próprio messias e, por isso, a partir de uma hermenêutica teológica, da mesma natureza divina do seu Pai: "Diz a ele a mulher: sei que o messias chamado cristo vem; quando vier aquele, anunciará a nós todas as coisas. Diz a ela Jesus: eu sou o que

${ }^{32}$ FIGUEREDO, Pedro. A questão do Logos e os discursos de Jesus no Evangelho de São João, p. 42.

33 LATOURELLE, René. Teologia da Revelação. São Paulo: Paulinas, 1972, p. 78.

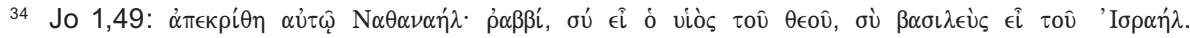

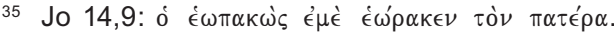

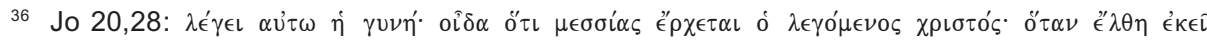
$\nu 0 \varsigma, \dot{\alpha} \nu \alpha \gamma \gamma \in \lambda \in \hat{\imath} \quad \dot{\eta} \mu \hat{\imath} \nu \ddot{\alpha}^{\prime \prime} \pi \nu \tau \tau$.

37 FIGUEREDO, Pedro. A questão do Logos e os discursos de Jesus no Evangelho de São João, p. 45. 
fala a ti";38 assim como ele também afirma: "Eu sou o pão da vida..." (Jo 6,35);39 "Disse a eles Jesus: Amém, amém digo a vós, antes de Abraão vir a ser eu sou" (Jo 8,58); 40 "Eu sou a ressurreição e a vida; o que crê em mim mesmo se morrer viverá" (Jo 11,25); "41 "Eu sou o caminho e a verdade e a vida; ninguém vem ao Pai se não por meio de mim" (Jo 14,6). ${ }^{42}$

\subsection{O Logos como revelador da Divindade}

"Deus ninguém viu nunca; o único Deus que está no seio do Pai, este o revelou" (Jo 1,18). ${ }^{43}$ O Logos aqui é apresentado como o revelador, em plenitude, do Pai à humanidade. Ele é a via para se conhecer o Pai: a revelação do amor (Jo 3,16), da vontade (Jo 3,16-18), da verdade (Jo 8,32;14,6), da luz (Jo 8,$12 ; 9.5$ ), da vida (Jo 3,17-18;3,36;5,25;6,68;10,10;20,31), e da salvação da humanidade (Jo 17,21). Ora, ao mesmo tempo em que Cristo revela o Pai, torna-se a si mesmo revelado como Deus: ao revelar, ele é revelado; ele é o Deus que fala e o Deus do qual se fala. ${ }^{44}$

Em Jo 14,17 Jesus, ao falar do conhecimento do Pai, usa uma condicional: "Se tendes conhecido a mim, também o meu Pai conhecereis. E desde agora conheceis a ele e vistes a ele" (Jo 14,7), ${ }^{45}$ quer dizer, a condição para conhecer a Deus, é conhecer o Filho, que expressa Deus e é o próprio Deus, como o próprio Cristo afirma: "Eu e o Pai somos um" (Jo 10,30). Novamente o número 'um' ('́v), aqui expresso, indica uma unidade completa em si mesma (número cardial no neutro singular).

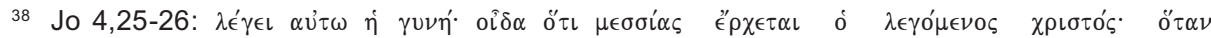

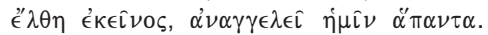

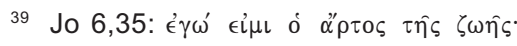

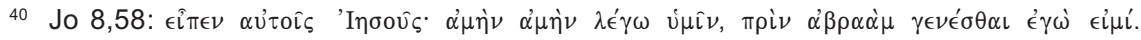

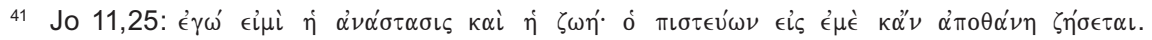

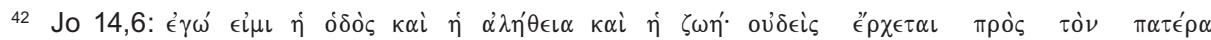

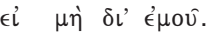

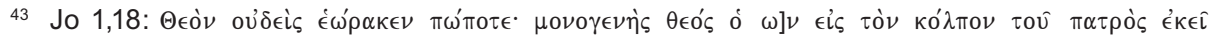

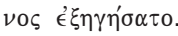

44 LATOURELLE, René. Teologia da Revelação, p. 82.

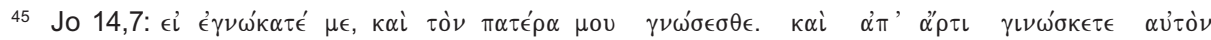
$\kappa \alpha \iota \dot{\epsilon} \omega \rho \alpha \dot{\kappa} \alpha \tau \epsilon \alpha u^{\prime \tau o ́} \nu$.
} 
Fundamentalmente, é necessário destacar que, como revelador do Pai, o logos tornou visível o amor de Deus à humanidade (Jo 3,16); declarou a vontade soberana do Pai, a salvação da humanidade (Jo 3,17-18); manifestou a verdade libertadora à humanidade (Jo 8,32); tornou perceptível e visivel a luz esclarecedora de Deus à humanidade (Jo 8,12); trouxe a vida eterna à humanidade (Jo 3,36 ); tornou real a esperança divina à humanidade (Jo $14,1-3) .{ }^{46}$

\subsection{O Logos e a Criação}

"Todas as coisas por meio dele foram feitas, e sem ele nenhuma coisa foi feita" (Jo 1,3). ${ }^{47}$ Aqui, o logos aparece como a causa de todas as coisas criadas, seja as visíveis como as invisíveis. A preposição $\chi \omega$ pís indica causalidade e presença do logos na criação de todas as coisas, pois constituem dois elementos inseparáveis, em que um necessita do outro. É por isso que "João afirma que 'no princípio era o logos' [...], destacando a presença eterna do mesmo, e 'todas as coisas por intermédio dele surgiram, e aparte dele nem uma só coisa surgiu"'. ${ }^{48} \mathrm{O}$ logos, portanto, é o gerador de todas as coisas.

No texto de $\mathrm{Cl} 1,16-17$, também se observa este relacionamento do logos com a criação: "Porque nele foram criadas todas as coisas nos céus e sobre a terra, as visíveis e as invisíveis, sejam tronos sejam soberanias principados sejam poderes; todas as coisas por meio dele e para ele foram criadas". ${ }^{49}$ Ora, o verbo $\kappa \tau i \zeta \omega$ quer dizer criar, uma terminologia utilizada pelos gregos para falar da fundação das coisas, mas não de algo criado pelo acaso e sim de uma criação minuciosa, cuidada. Já o pronome demonstrativo aủtós reforça a idéia de que o logos é o autor e sustentador de tudo quanto existe. Pois

46 FIGUEREDO, Pedro. A Questão do Logos e os Discursos de Jesus no Evangelho de São João, p. 70-73.

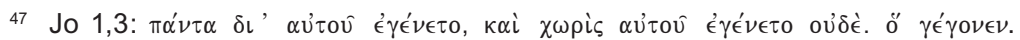

48 FIGUEREDO, Pedro. A Questão do Logos e os Discursos de Jesus no Evangelho de São João, p. 50.

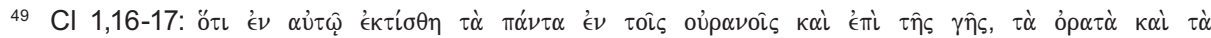

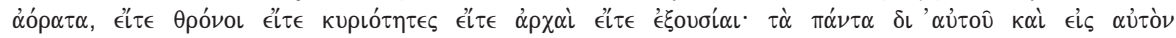

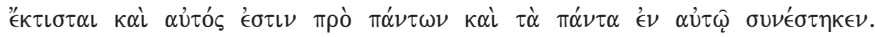


ele é a existência de si mesmo. Pois, assim como "Jesus e o Pai são uma mesma realidade salvífica, assim também sucede no plano da criação". 50

A Epístola aos Hebreus 1,1-2 prescreve: "Muitas vezes e de modos diversos falou Deus, outrora, aos pais pelos profetas; agora, nestes dias que são os últimos, falou-nos por meio do Filho, a quem constitui herdeiro de todas as coisas, e pelo qual fez os séculos [...]" ${ }^{51}$ Cristo, aqui, é apresentado como o herdeiro de tudo quanto existe e as coisas, somente por ele, foram criadas. Por isso, o Logos é o ordenador e governador de todas as coisas criadas, desde sempre, de todo o princípio.

\subsection{O Logos e a Encarnação}

"E o verbo se fez carne e morou entre nós, e vimos a glória dele, glória como de único Pai, pleno de graça e de verdade" (Jo 1,14). ${ }^{52}$ João demonstra a eternidade do Logos e sua inserção na história, como homem. O termo $\sigma \alpha ́ \rho \xi$ demonstra que Cristo tornou-se verdadeiramente homem, repleto de toda natureza humana, menos no pecado. O "tornar-se carne" (que vem do hebraico bassar) compreende o homem na sua totalidade. ${ }^{53} \mathrm{Ele}$, o Cristo Jesus, nasceu de uma mulher (Mt 1,18-25; Lc 1,26-35), passou pelas etapas da infância e juventude (Mt 2,14, 19-21; Lc 2,21-24.39-52) e fase adulta (Mt 3,$1 ; 28,1-20 ;$ Mc 1.9; 16,1-20; Lc 3,21; 24,1-53; Jo 1.15; 21,1-25). E como homem desenvolveu-se segundo a natureza humana: sentiu fome (Mt 4,2; Lc 4,2), bebeu (Jo 4,7), enfrentou o cansaço e a dor (Mt 26,67-68; 27,2629.32-56; Mc15,21-47; Lc 23,26-48; Jo 19,17-37), a tristeza (Mt 26,36-46; Mc 14,32-42), as tentações (Mt 4,1-11; Lc 4,1-13), a indignação (Mc 10,13-14). Como homem, também orava (Mt 14,23;26,36.44; Mc 1,35;6,46; 14,32; Lc $3,21 ; 5,16 ; 6,12 ; 9,28 ; 11,1)$, digiria-se ao templo (Lc 4,$16 ; 18,10)$, enfrentou a morte de cruz (Mt 27,32-56; Mc 15,21-41; Lc 23,33-48; Jo 19,17-37). E

50 CALLE, Francisco de La. A teologia do Quarto Evangelho, p. 43.

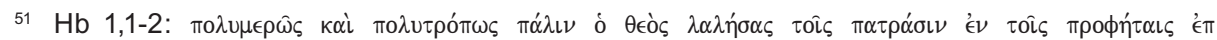

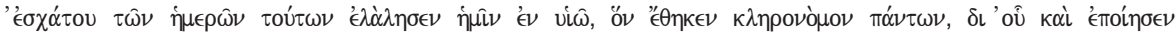

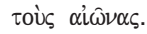

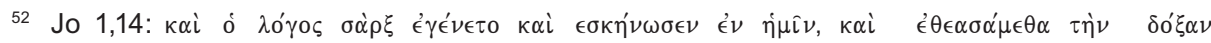

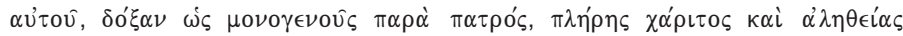

53 CHOURAQUI, André. A Bíblia: lahonan, p. 50. 
como homem repleto de Deus, por ser o próprio Deus, cresceu em estatura e sabedoria (Lc 2,52). ${ }^{54}$

O Logos, desde sempre, foi Deus. E a encarnação surge como "uma obra de amor incompreensível, e de uma infinita condescendência". ${ }^{55}$ Ao encarnar a natureza humana, comporta em si duas naturezas, distintas, porém unidas numa só pessoa:

Enquanto Deus, Jesus continuou a ser detentor de atributos e de uma natureza divina, ainda que muitas vezes a manifestava oculta. Enquanto homem, Jesus nunca se despojou da sua humanidade, nunca deixou de estar sujeito às mesmas tentações e provações que nós, mas em tudo foi mais do que vencedor. ${ }^{56}$

E porque Jesus é homem e Deus, torna-se o mediador, por excelência entre a humanidade e o Pai, assim como afirma São Paulo: "Pois um só é Deus e um só mediador entre Deus e os homens, um homem, Cristo Jesus, que se deu em resgate por todos. Este é o testemunho dado em tempos próprios" (1Tm 2,5). ${ }^{57}$

Ele, o messias, experienciou todas as aflições e fragilidades humanas; como Deus, intercedeu por cada homem a fim de que alcançasse a salvação. $\mathrm{O}$ dito de Paulo, acima destacado, apresenta o verbo $\epsilon i \mu$ í, que quer significar a existência de um só Deus, aquele que é o mediador entre Deus e os homens; o número $\epsilon$ ís quer significar a existência de uma unidade singular, definitiva, determinada, para significar Jesus como ó único mediador entre Deus e a humanidade.

\subsection{O Testemunho de João Batista}

"Houve um homem enviado da parte de Deus, seu nome era João, este veio como testemunha, para dar testemunho a respeito da luz, afim de que

54 FIGUEREDO, Pedro. A Questão do Logos e os Discursos de Jesus no Evangelho de São João, p. 62.

55 HENDRIKSEN, William. O Evangelho de João, p. 101.

56 FIGUEREDO, Pedro. A Questão do Logos e os Discursos de Jesus no Evangelho de São João, p. 64.

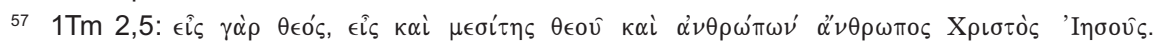


todos crescem por meio de ele. Ele não era a luz, mas veio para dar testemunho da luz". (Jo 1,6-8). ${ }^{58}$ João Batista é apresentado, pelo Evangelista, como um enviado de Deus, alguém que veio para preparar os caminhos do Senhor (Lc 3,4-6). Ele, João, que nasceu por intervenção divina (Lc 1,520), recebeu a missão de batizar (LC 1,15-17) e anunciar a vida de Cristo ao mundo (LC 3,6.16-18).

João Batista é aquele que veio para ser testemunha da luz, quer dizer: como enviado, ele tem a função de apresentar, de trazer Deus no seio da humanidade. A missão de João Batista quer significar a missão de todo cristão: dar testemunho de Cristo, como luz do mundo e para a humanidade. Em vários momentos, nos seus escritos, o Evangelista João sublinha esta idéia do testemunho, como missão de todo aquele que é enviado: a mulher samaritana testemunhou que Jesus era o Cristo (4,28-30); os samaritanos testemunharam do que ouviram e creram em Jesus como salvador do mundo (4,39-42); o Pai testemunhou o seu Filho amado (5,37); as próprias Escrituras testemunharam de Jesus $(5,39)$; os sinais realizados pelo Messias testemunharam Jesus (5,36); a multidão que viu os seus sinais testemunhou Jesus $(12,17)$; o Espírito Santo dá testemunha de Jesus $(15,26)$; os discípulos, as testemunhas de Jesus $(15,27)$; o apóstolo João, testemunha de Jesus $(19,35) .{ }^{59}$

"Este testemunho fala diversas vezes da missão e, sobretudo, apresenta Jesus como o grande enviado "Enviado do Pai". Talvez os fiéis da comunidade joanina se reconhecessem na figura do Enviado". ${ }^{60}$

João Batista é um enviado da parte de Deus! Esta expressão transmite uma idéia que João Batista é um representante de Deus para testemunhar o messias, por isso "a intenção de João era que todos os que ouvissem seu testemunho pudessem ter uma fé viva em Cristo". ${ }^{61}$ Ora, vir da parte de Deus significa ter uma identificação com os planos de Deus, que não se

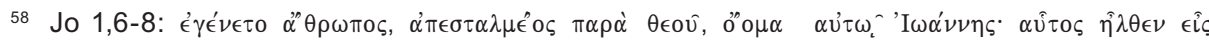

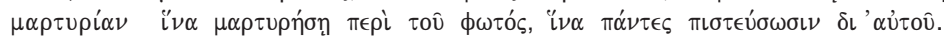

59 FIGUEREDO, Pedro. A Questão do Logos e os Discursos de Jesus no Evangelho de São João, p. 75-79.

60 KONINGS, Johan. Evangelho Segundo João, Amor e Fidelidade. São Paulo: Loyola, 2005, p. 51.

61 HENDRIKSEN, William. O Evangelho de João, p. 109.
} 
efetiva por vontade propriamente humana, mas por intermédio divino e, por isso, toda testemunha, enviado, só se torna eficaz se proceder de Deus e atuar em plena comunhão com ele.

Impressiona a humildade de João Batista que, ao revelar, não poder sequer desamarrar as sandálias de Cristo (Jo 1,27). Esta postura evidencia a grandeza com que João pensava Jesus: uma pessoa repleta de Deus, o salvador do mundo, como ele mesmo, João, exclama: "Eis o cordeiro de Deus, que tira o pecado do mundo" (Jo 1,29). ${ }^{62}$ O título "cordeiro" é raro no Novo Testamento, somente depois em Apocalipse irá encontrar. Cordeiro, aqui, pode remeter os cordeiros oferecidos pelos judeus a fim de expiar os pecados. Na base, está a idéia de purificação e o logos é aquele que tira o pecado, mas não um pecado individualista e sim a corrupção do mundo, que reside desde o início do mundo. ${ }^{63}$ Importa, aqui, salientar alguns aspectos de suma importância sobre o testemunho de João Batista: a) somente Jesus é a luz dos homens. Embora venha de Deus, João não é a luz, mas testemunha a luz (Jo 1,6-8); o que veio depois de João é antes dele. João Batista tem a missão de testemunhar a eternidade do messias (Jo 1,15); João afirmou que não era o Cristo. Neste sentido, a missão de João Batista também se prescreve na tentativa de esclarecer quem é, de fato, o messias; ele mesmo era apenas uma testemunha entre outras. Tem a missão de preparar o caminho do Senhor (Jo 1,21-23); Jesus era infinitamente mais digno do que ele. Exclamação que representa a profunda humildade de João em referência ao messias (Jo 1,25-27). ${ }^{64}$

\subsection{O Logos e a Humanidade}

"E a vida era a luz das pessoas" (Jo 1,4b). ${ }^{65}$ A vida em Cristo é a luz para a toda a humanidade, pois somente nele o homem encontra vida. Os dois substantivos $\zeta \omega \eta$ ' e $\phi \omega \varsigma$, respectivamente "vida" e "luz", "têm como função determinar a existência presente e futura da humanidade. O homem,

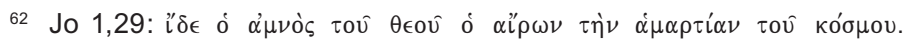

63 KONINGS, Johan. Evangelho Segundo João, Amor e Fidelidade, p. 91-92.

64 FIGUEREDO, Pedro. A Questão do Logos e os Discursos de Jesus no Evangelho de São João, p. 82-84.

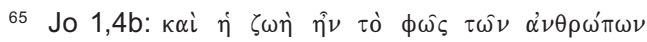


enquanto criatura de Deus, sempre depende da vida e da luz do Criador". ${ }^{66}$ Isentar-se desta graça é viver num mundo obscuro, marcado pelo caus. A terminologia, aqui apresentada, refere-se à plenitude da essência de Deus: verdade, sabedoria, onipotência, soberania. "É dito que essa vida divina, plena e abençoada, sempre esteve presente na Palavra, por toda a eternidade, e durante toda a antiga dispensação: 'Nele estava a vida'". 67

Ao seguir o texto, em Jo 1,5 se diz que "E a luz brilha na escuridão e a escuridão a ela não venceu". ${ }^{68}$ Neste versículo nota-se o poder da luz

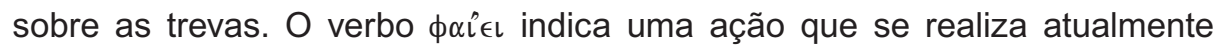
na tentativa de demonstrar que a luz, ainda hoje, vence o poder das trevas. Por isso tal ação acontece sempre no presente (o verbo está no presente do indicativo). Já o verbo $\kappa \alpha \tau \epsilon ́ \lambda \alpha \beta \in \nu$ (no aoristo modo indicativo) expressa a idéia de que não somente as trevas não compreenderam a luz, assim como elas não venceram a luz, isto quer dizer: as trevas não dominaram a luz (como um fato acontecido na história), mas a luz continua agir sobre as trevas (uma ação que repercute).

"Era a luz verdadeira, a qual ilumina todo ser humano, que vinha ao mundo" (Jo 1,9). ${ }^{69}$ Aqui João apresenta a qualidade desta luz: a verdade. Não é uma luz como tantas outras, mas uma luz que é verdadeira. Verdade que expressa, também, a função do ministério de Cristo: trazer e evidenciar a verdade para o mundo, porque ele é verdade. Por isso o logos é a verdade. No entanto, o mundo não conheceu Cristo, como prescreve João no versículo seguinte $(1,10)$ : "Em o mundo estava, e o mundo foi feito por meio dele, e o mundo a ele não conheceu" ${ }^{70}$

Ora, o logos, criador de todas as coisas, não foi reconhecido pelo mundo. Este conhecimento não se reduz no plano entendimento (na tentativa de identificar a sua verdade), mas refere-se no relacionamento entre ele e o mundo, isto é, entre criador e criatura. Esta relação, entre o logos e a criação, se

\footnotetext{
66 FIGUEREDO, Pedro. A Questão do Logos e os Discursos de Jesus no Evangelho de São João, p. 56.

67 HENDRIKSEN, William. O Evangelho de João, p. 105.

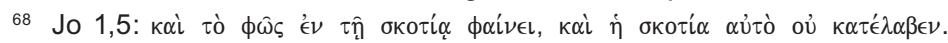

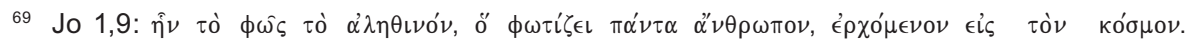

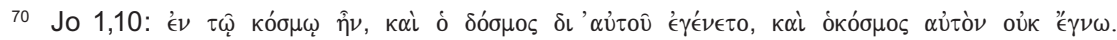


caracteriza pelo fato de: a) O logos é a luz divina que expressa o próprio sentido da humanidade (Jo 1,4); b) Ele é a luz divina que necessita ser amada pela humanidade (Jo 3,19); c) É aquele que ilumina a humanidade (Jo 12,35); d) É a luz divina que trás vitória sobre as trevas (Jo 1,5). ${ }^{71}$

\section{CONCLUSÃO}

Partindo da reflexão acima verificamos a solidez com que foram desenvolvidos os escritos do quarto evangelho, pois, o Logos nos é apresentado como sendo o centro e elemento necessário para a compreensão de todo o texto; trata-se do próprio Deus que se fez homem (carne) para resgatar não somente o homem, mas, toda a criação.

Esta teologia cristocêntrica também nos apresenta os fundamentos para o símbolo niceno-constantinopolitano no que se refere a Jesus:

"[...] Creio em um só Senhor, Jesus Cristo, Filho unigênito de Deus, nascido do Pai antes de todos os séculos. Deus de Deus, luz da luz, Deus verdadeiro de Deus verdadeiro, gerado, não criado, consubstancial ao Pai. Por ele todas as coisas foram feitas. E por nós, homens, e para nossa salvação desceu dos céus, e se encarnou pelo Espírito Santo no seio da Virgem Maria e se fez homem [...]".

$\mathrm{Na}$ eternidade do Logos, João vai buscar a origem da fé de sua comunidade. Tal origem vai além dos antepassados apontados pelos sinóticos, como Adão, Abraão, Moisés, etc. Essa origem abarca o começo do universo para nos remeter ao limiar da história até a mais profunda intimidade de Deus para nos unir ao que diz o SI 139,22: “[...] é Ele quem me conduz pelo caminho eterno". O Logos não pode ser entendido por meio de categorias temporais, pois sua pré-existência está no âmbito de Deus. Portanto, o Logos se relaciona com Deus. Ele é o revelador da divindade, da qual dele emana para a criação e encarnação. O seu testemunho foi dado por meio de

71 FIGUEREDO, Pedro. A Questão do Logos e os Discursos de Jesus no Evangelho de São João, p. 59-61. 
João Batista, o enviado de Deus. O mundo, porém, o rejeitou, mas o Logos continua sendo a luz da humanidade e a gloriosa vitória sobre a escuridão.

\section{BIBLIOGRAFIA}

CALLE, Francisco de La. A Teologia do Quarto Evangelho. (trad.) José Raimundo Vidigal. São Paulo: Paulinas, 1985.

CHOURAQUI, André. A Bíblia: lahonan (O Evangelho segundo João). Rio de Janeiro: Imago, 1997.

CULLMANN, Oscar. Cristologia Del Nuevo Testamento. (trad.) Carlos T. Gattinoni e Xavier Pikaza. Salamanca: Sígueme, 1997.

FIGUEREDO, Pedro. A Questão do Logos e os Discursos de Jesus no Evangelho de São João. In Revista de Ciência das religiões. Vol. I. (2008), p. 34.

HENDRIKSEN, William. O Evangelho de João. São Paulo. (trad.) Elias Dantas e Neuza Batista. São Paulo: Cultura cristã, 2004.

LATOURELLE, René. Teologia da Revelação. São Paulo: Paulinas, 1972.

LÉON-DUFOUR, Xavier. Leitura do Evangelho Segundo João. Vol. I. São Paulo: Loyola, 1996.

BENTO XVI. Exortação Apostólica Pós-sinodal, Verbum Domini, São Paulo, Paulinas, 2010.

RUSCONI, Carlos. Dicionário do Grego do Novo Testamento. São Paulo: Paulus, 2005. 